\title{
IMPORT COMPETITION AND LABOUR PRODUCTIVITY IN NIGERIA
}

\author{
Oziengbe Scott Aigheyisi \\ Department of Economics, University of Benin, Benin City, Nigeria \\ oziengbeaigheyisi@gmail.com
}

\begin{abstract}
The paper examines the effects of import competition and other factors such as capital intensity, foreign direct investment (being a channel through which foreign technologies are transmitted into an economy) and access to electricity, on labour productivity in Nigeria using annual time series data spanning the period from 1991 to 2018. In doing this, the FMOLS estimator is employed for estimation of a long run cointegrating model. The study finds that import competition adversely affects labour productivity in the long run. It also finds that the effect of capital intensity on labour productivity is positive, but not statistically significant. Further evidence from the study are that foreign direct investment and access to electricity positively and significantly affect labour productivity in the country. The study recommends, as measures to increase labour productivity in the country, efforts by the government to improve access to electricity, enhance the attractiveness of various sectors of the economy to FDI, and boost domestic production capacity to increase volume and quality of output so as to enhance its competitiveness and reduce dependence on imports, especially of consumption goods.
\end{abstract}

Keywords: Import Penetration, Access to Electricity, Foreign Direct Investment, Capital intensity, Labour productivity, Nigeria.

JEL Classification: E24, F16, J24.

\section{Introduction}

Import competition, also referred to as import penetration is the share of imports in total domestic demand. It indicates the extent to which domestic demand is satisfied by imports. A country with high rate of import competition or import penetration relies heavily on imports to meet its domestic demand. One of the reasons for high import penetration in less developed countries (LDCs) is low level of output. Where output level is low, a country may have to either rely on imports to meet its domestic demand, or attract multinational corporations through which foreign direct investment (FDI) is channeled into an economy, to complement domestic production, thereby raising output levels. However, the WTO (1984) has demonstrated that high import penetration is not peculiar with LDCs alone, as industrialised and highly developed countries may also have high rates of import penetration or import competition as a result of intensification of intra-industry trade. This is trade in differentiated products such as textiles, automobile, etc. which is characteristic of trade between or among industrialised countries, and accounts for the largest share of global trade (Turcan and Ates, 2010).

From a macroeconomic perspective, labour productivity refers to output per unit of labour employed (ILO, n.d.). This is one of the commonest measures of labour productivity, and it is affected by myriads of factors. In this study, we examine whether or not import competition plays any role in labour productivity. Import competition could have mixed consequences for labour productivity depending on the structures of industries in the economy - that is whether they are concentrated or fragmented (MacDonald, 1994), and how an economy responds to it. A fragmented industry is one with many competing firms, where no single or small group of firms dominates. A concentrated industry is one dominated by a single firm or 
a few firms. Labour productivity effect of Import competition could be positive in (an economy with) concentrated industries; it could be non-significant in (an economy with) fragmented industries. The effect of import competition on labour productivity in an economy could be positive if industries in the country become more technically efficient by taking advantage of the knowledge spillover (positive externality) effect of learning, by investing in training (human capacity development), research and development (R\&D) so as to copy foreign technology used for production of items facing stiff competition with imports in the domestic or home market. This has the potential to boost production per labour employed. At firm level, the positive effect of competition on productivity has been linked to improvement in management quality it engenders. The argument has been that competition leads to improvement in management quality, which in turn leads to improved productivity (Reenen, 2010).

The effect of import competition on labour productivity could be adverse where import becomes more competitive than locally made goods in the domestic market. This may discourage local production, and adversely affect wages and productivity. Most LDCs are ill-prepared for the new wave of globalization and its attendant competitive pressures to which infant industries are exposed. Considering that these countries little or no capacity to absorb the ascribed benefits of globalization the effect of import competition on labour productivity may not be benign. This will be empirically investigated in this paper using Nigeria as the country in focus.

Nigeria is a lower-middle income country, according to the recent World Bank's classification (World Bank, 2019). The country is highly dependent on imports. Her imports range from basic primary commodities such as agriculture and other raw/crude materials, to manufactures and technology goods. Labour productivity in the country has not been impressive (Akinleye, 2007). Though several studies (Fagbenle, Ogunde and Owolabi, 2011; Umoru and Yaqub, 2013; Muhammad et al, 2015; Jimoh, Oyewobi, Suleiman and Isa, 2017) have attempted to explain the poor productivity of labour in Nigeria, to the best of our knowledge, none have considered the potential role of import competition in explaining labour productivity in the country. Considering that import competition in the country is quite intense as a result of her high dependence on imports, investigating whether import competition plays any role in labour productivity in the country is not out of place in view of the fact that labour productivity is a key factor for sustainable growth and development as seen in various growth theories (Krugman, 1995; ILO, n.d; Nekrep, Strašekand Boršič, 2018). High labour productivity enhances economic growth, while low labour productivity impedes it. The objective of this paper is to investigate the effect of import competition on labour productivity in Nigeria. To the best of our knowledge, though several researchers have examined the effect of import competition on labour productivity in other countries or regions, the labour productivity effect of import penetration in Nigeria is yet to be investigated. This study contributes to extant knowledge in this discourse by bridging this gap.

\section{Literature Review}

The study by MacDonald (1994) on the effect of import competition on labour productivity involving 94 manufacturing industries in the U.S. found that import competition positively affected labour productivity in highly concentrated industries during the 1975-1987 period. This effect did not occur contemporaneously, but with a lag of one period (year). The study found no significant effect of import competition on labour productivity in less concentrated industries.

Bloch and McDonald (2001) examined the impact of import competition on labour productivity using panel dataset on Australian manufacturing firms for the period 1984 to 1993. The study found positive impact of import competition on labour productivity. It also found an interaction between import competition and domestic competition. The positive 
impact of import competition on growth of labour productivity rose with the extent of competition among domestic producers. The results, according to the researchers suggest that less control on inflow of manufactured imports by way of lowering of border protection enhanced productivity of labour in concentrated industries.

Ospinar and Schiffbauer (2010) utilized firm-level observations from the World Bank's Enterprise Survey database to investigate the effect of import competition on firm productivity in emerging market countries of Eastern Europe and Central Asia. The study found positive relationship between import competition and productivity, and this relationship was robust to alternative measures of both variables. It also found that countries that embarked on product-market reforms experienced higher level of import competition which in turn engendered enhancement of their firms' productivity. Specifically, increase in import competition due to product market reform accounted for $12 \%-15 \%$ of growth in productivity. Murphy and Siedschlag (2012) examined the effects of changes in international competitiveness on labour productivity growth through the channels of export, import and import competition using micro-data on Irish manufacturing firms during the period from 1995 to 2002. Among other findings, the study found that import competition resulting from appreciation of the real exchange rate had no significant effect of growth of firm's labour productivity.

Olper, Pacca and Curzi (2013) examined the effect of import penetration on productivity growth in Europe during the period from 1995 to 2008. The study covered 9 industries from 25 European countries. Different dynamic panel estimators were used for the analysis. The study found that increase in import penetration was "systematically positively related" to productivity growth. The positive effect of import penetration on productivity growth was robust to alternative measures of productivity and it was driven by competition in final products from developed countries, particularly the EU-15 countries.

Doan, Nguyen, Vu, Tran and Lim (2014) investigated whether import competition harms productivity of local firms in less advanced economies. In the study, panel and instrumental variable methods were employed for analysis of unbalanced panel dataset covering the period from 2000 to 2009 on firms in Vietnam's manufacturing sector. The study found that import competition negatively and significantly affected productivity of local firms in the country's manufacturing sector.

Ding, Sun and Jiang (2015) examined whether the distance to technology frontier matters in the effect of import competition on firm productivity and innovation in China. The study found that import penetration positively affected firms' productivity growth and their expenditure in $R \& D$ if firms and industries in which they belong were close to the world's technology frontier. However, from lagging firms and industries, which are far from the frontiers of global technology, the productivity growth and innovation effects of import penetration or competition was adverse.

The study by Yahmed and Dougherty (2016) on the effects of domestic regulation and import penetration on firm-level productivity growth in OECD countries during the 1990s to late 2000s revealed that import penetration positively affected productivity growth of firms that were close to the technology frontier and this effect was enhanced by less stringent domestic regulations. However, for firms that are not close to the technology frontier, the effect of import competition on productivity growth was not statistically significant. For these firms, the effect of interaction of import competition with domestic regulation on firm-level productivity growth was also not statistically significant. This suggests that domestic regulation has no bearing on the effect of import competition on firm-level productivity in the countries.

Dhyne, Petrin, Smeets and Warzynski (2016) investigated the effect of import competition on firm product-level productivity in Belgium during the period from 1995 to 2007 . Ordinary least squares and instrumental estimations were performed for the investigation. The study found that increased import competition was associated with rise in firms' product-level 
productivity. A $10 \%$ rise in import completion was found to be associated with same percentage rise in technical efficiency.

\section{Methodology}

\subsection{Key Variables and their Measurements Labour Productivity:}

This study adopts the approach of the ILO (n.d.). Labour productivity is measured as real GDP per labour employed.

Labour Productivity $=\frac{\text { Real GDP }}{\text { Labour Employed }}$

Data on this measure of labour productivity (that is, Real GDP per labour employed) were obtained from the World Bank's World Development Indicators (2018).

\section{Import Competition (Import Penetration):}

Following WTO (1984) we measured import competition as the ratio of imports to domestic demand.

Import Competition $=\frac{\text { Imports }}{G D P-X+M}$

Where GDP $=$ Nominal Gross Domestic Product, $X=$ Value of export, $M=$ Value of imports, and $(\mathrm{GDP}-\mathrm{X}+\mathrm{M})=$ Domestic Demand.

\subsection{Model Specification}

The basic Solow growth model provides the theoretical framework for this study. Output is expressed as a function of production inputs (capital and labour).

$Y=f(K, L)$

Where $Y$ is real output, $K=$ physical capital stock and $L=L$ Labour employed. Expressing $Y$ in terms of per unit of capital employed, we have:

$Y / L=f(K / L, 1)$

$y=f(k)$

Where $y=Y / L=$ Labour productivity (as defined above), and $k=K / L=$ capital intensity.

Equation [3] expresses labour productivity as a function of capital intensity. To capture the effect of import competition on labour productivity, we incorporate this variable in equation [3]. Incorporating the variable in the model is in sync with theoretic predictions on effect of global trade in an economy, and also in line with previous empirical studies such as Doan et al, 2014 and Ding et al, 2015.

$y=f(k$, imcom, $X)$

The variables are as previously discussed. $X$ represents other variables affecting labour productivity such as foreign direct investment and access to electricity.

The labour productivity model is therefore expressed functionally as:

RGDPPL $=f(k$, imcom, nFDI, AELEC $)$

[5]

The econometric specification of the model is represented as:

$\ln \left(R_{\text {RGPPL }}\right)=\delta_{0}+\delta_{1} \ln \left(\mathrm{k}_{\mathrm{t}}\right)+\delta_{2}$ imcom $_{\mathrm{t}}+\delta_{3} \ln \left(\mathrm{nFDI} \mathrm{I}_{\mathrm{t}}\right)+\delta_{4} \mathrm{AELEC}_{\mathrm{t}}+\mu_{\mathrm{t}}$

Where RGDPPL = Real GDP per labour employed adjusted for purchasing power parity (measure of labour productivity), nFDI = net foreign direct investment inflow (BoP, current US\$), AELEC = Access to electricity (\% of population), $\mu$ is the error term. Other variables are as previously defined.

The a priori expectations are: $\delta_{1}>0, \delta_{2}<>>0, \delta_{3}>0, \delta_{4}>0$. Capital intensity is expected to enhance labour productivity. Increase in capital per labour is expected to engender increase in output per labour, ceteris paribus. There is no theoretical consensus on the effect of 
import penetration on labour productivity. Its effect depends on the absorptive capacities of countries. The effect may be positive in countries with high absorptive capacity, and potential of learning by doing; it may be negative in LDCs with less potential of learning by doing. Thus, the effect is indeterminate. Inflow of foreign direct investment which is a key channel through which foreign technology flows into a country, is expected a priori, to positively affect labour productivity, through technology spill-over effects. Improved access to electricity is also expected to positively affect labour productivity as uninterrupted electricity (power supply) enhances productivity, all things being equal.

The single equation fully modified ordinary least squares (FMOLS) estimation technique developed by Phillips and Hansen (1990) was used to estimate the model. The choice of this estimator was informed by the fact that it corrects the problems of endogeneity and serial correlation to yield optimal long run estimates of cointegrating model. A condition for employing this estimator is that the variables must be cointegrated. Thus long run relationships among the variables were tested using the Johansen cointegration procedure. Prior to the cointegration test, the variables were tested for unit root using the augmented Dickey Fuller (ADF) test and the Dickey-Fuller Generalised Least Squares (DF-GLS) test to determine their stationarity properties.

\subsection{Data}

Annual time series data on all the variables, spanning the period from 1991 to 2018 were used for the analysis. The scope was guided (dictated) by data availability. All data were sourced from the WDI database (2018).

\section{Results and Discussions}

\subsection{Unit Root and Cointegration Tests}

The result of the unit root test involving the ADF and the DF-GLS tests is summarized in Table 1.

Table 1: Summary Unit Root Test

\begin{tabular}{|c|c|c|c|}
\hline \multicolumn{4}{|c|}{ ADF Unit Root Test } \\
\hline \multirow[t]{2}{*}{ Variables } & \multicolumn{2}{|c|}{ First Difference } & \multirow[t]{2}{*}{$d^{*}$} \\
\hline & ADF test stat. & Critical Value (5\%) & \\
\hline $\ln (\mathrm{RGDPPL})$ & -3.94 & -2.98 & 1 \\
\hline $\ln (k)$ & -6.06 & -3.61 & 1 \\
\hline Imcom & -6.33 & -3.60 & 1 \\
\hline $\ln (\mathrm{nFDI})$ & -5.87 & -3.60 & 1 \\
\hline AELEC & -5.05 & -3.64 & 1 \\
\hline \multicolumn{4}{|c|}{ DF-GLS Unit Root Test } \\
\hline \multirow[t]{2}{*}{ Variables } & \multicolumn{2}{|c|}{ First Difference } & $d^{*}$ \\
\hline & DF-GLS test stat. & Critical Value (5\%) & \\
\hline $\ln (\mathrm{RGDPPL})$ & -3.97 & -3.19 & 1 \\
\hline $\ln (\mathrm{k})$ & -6.31 & -3.19 & 1 \\
\hline Imcom & -6.60 & -3.19 & 1 \\
\hline $\ln (\mathrm{nFDI})$ & -6.11 & -3.19 & 1 \\
\hline AELEC & -8.38 & -3.19 & 1 \\
\hline
\end{tabular}

Source: Author's Estimation using EVIEWS 9 
The unit root's test results indicate that the variables are stationary at first differences. In spite of this, there is the tendency for them to converge in the long run. This was tested using the Trace test of the Johansen cointegration test. The result is presented in Table 2.

Table 2: Cointegration Test

\begin{tabular}{|c|c|c|c|c|}
\hline \multirow{2}{*}{\multicolumn{5}{|c|}{$\begin{array}{l}\text { Sample (adjusted): } 19932016 \\
\text { Included observations: } 24 \text { after adjustments } \\
\text { Trend assumption: Linear deterministic trend } \\
\text { Series: In(RGDPPL) In(k) Imcom In(nFDI) AELEC } \\
\text { Lags interval (in first differences): } 1 \text { to } 1 \\
\text { Unrestricted Cointegration Rank Test (Trace) } \\
\end{array}$}} \\
\hline & & & & \\
\hline \multirow{6}{*}{$\begin{array}{l}\text { Hypothesized } \\
\text { No. of CE(s) } \\
0 \text { * } \\
\leq 1 \\
\leq 2 \\
\leq 3\end{array}$} & & Trace & 0.05 & \\
\hline & Eigenvalue & Statistic & Critical Value & Prob. ** \\
\hline & 0.740542 & 74.14049 & 69.81889 & 0.0217 \\
\hline & 0.623884 & 41.76067 & 47.85613 & 0.1655 \\
\hline & 0.404528 & 18.29206 & 29.79707 & 0.5446 \\
\hline & 0.159709 & 5.850445 & 15.49471 & 0.7131 \\
\hline$\leq 4$ & 0.067383 & 1.674268 & 3.841466 & 0.1957 \\
\hline $\begin{array}{l}\text { Trace test indic } \\
{ }^{*} \text { denotes rejec } \\
{ }^{* *} \text { MacKinnon- } \mathrm{H} \\
\end{array}$ & $\begin{array}{l}\text { es } 1 \text { cointe } \\
\text { n of the hyr } \\
\text { g-Michelis }\end{array}$ & $\begin{array}{l}\text { eqn(s) at } \\
s \text { at the } 0 \\
p \text {-values }\end{array}$ & $\begin{array}{l}\text { D.05 level } \\
\text { evel }\end{array}$ & \\
\hline
\end{tabular}

Source: Author's Estimation using EVIEWS 9

The cointegration test result shows that the variables are cointegrated as one cointegrating equation is indicated by the Trace test. This suggests that a long run relationship exists between the dependent variable and the explanatory variables.

\subsection{Model Estimation}

Since the variables were found to be cointegrated, the FMOLS estimator was used to obtain efficient and consistent long run coefficients of the cointegrating model. The result of the estimation is presented in Table 3.

Table 3: Model Estimation Result

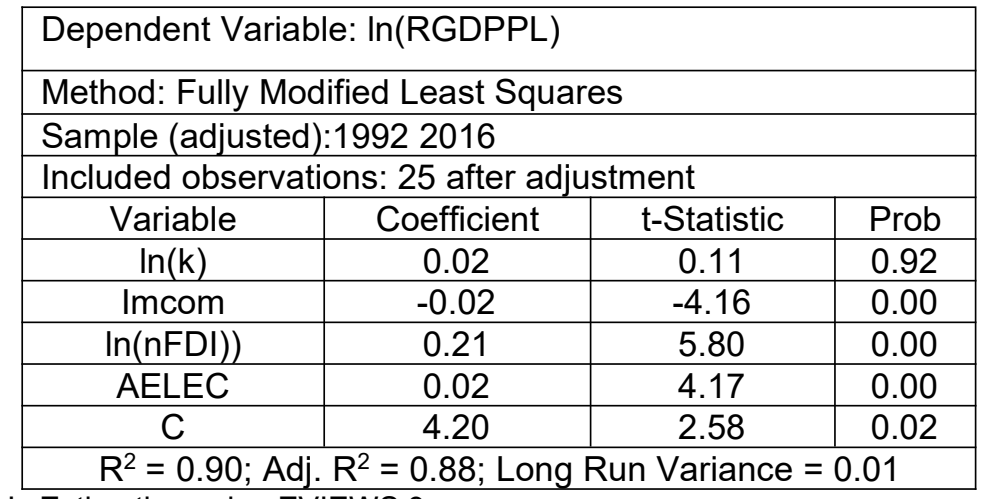

Source: Author's Estimation using EVIEWS 9

The result shows positive sign on the coefficient of capital intensity. This conforms to a priori expectation, though the coefficient is not statistically significant. This suggests that capital intensity in the country in the period under review did not contribute significantly to productivity of labour. It also suggests that the rate of capital formation in the country has 
been quite low and as a result, the variable did not contribute significantly to productivity of labour therein.

Import competition is observed to be negatively related to labour productivity in the long run in Nigeria, and the relationship is highly significant at the $1 \%$ level. This suggests that increase in import competition will adversely affect labour productivity in Nigeria in the long run. This result which is contrary to observations in developed and other emerging market countries such as the U.S. and China suggests that the country's industries are weak, making the economy less competitive. It is also an indication that the country is currently not fully prepared to for the vagaries of competition at the international level. Furthermore, the result suggests that the country's industries are far from the world's technology frontier. The observation corroborates evidence from the study by Doan et al (2014) which also found negative and significant effect of import competition on local manufacturing firms' productivity in less advanced country of Vietnam.

Foreign direct investment positively affects labour productivity as expected, and the effect is significant at the $1 \%$ level. This is not unexpected considering that FDI constitutes a mechanism through which technology which enhances productivity of labour is transferred into an economy. The more FDI the country attracts into various sectors of the economy, the more productive will be the labour employed in the production of its output as it adopts foreign advanced technologies for production. This observation corroborates evidence from previous studies such as Liu, Parker, Vaidya and Wei (2001), Ramirez (2006), and Boghean and State (2015) which also found positive effect of FDI on labour productivity.

Access to electricity is observed to be positively and significantly related to labour productivity. This conforms to a priori expectation. It suggests that increased access to electricity will enhance the productivity of labour employed for production in various sectors of the economy in the long run. This is in sync with results from Alam, Miah, Hammoudeh and Tiwari (2018) which also found that improved access to electricity will engender increase in labour productivity in the long run.

\section{Recommendations and Conclusion}

\subsection{Policy Recommendations}

Based on the empirical evidence, the following are proffered as recommendations for policy consideration:

i. There is need for the government to design, formulate and implement policies that are geared towards encouraging domestic investment to boost domestic output of goods and services, as well increase their competitiveness, curb demand for imports and stymie the adverse effect of import competition on labour productivity in the country. Specific measures in this regard include development of infrastructure (including roads, telecommunication, and other information technology infrastructure etc.), reduction in cost of doing business, favourable tax regimes, lowering the lending interest rate of the lending institutions through reduction of the monetary policy rate which is the benchmark interest (to ease access to investment credit), cautious control of imports, subsidizing some sectors of the economy (such as agriculture, etc.) and so on

ii. Efforts should be made to enhance the attractiveness of the country to FDI as this constitutes a main channel for transmission of foreign technology which enhances productivity of labour. Measures to enhance the attractiveness of the country to FDI include tackling the security challenges bedeviling the country, combating crimes, trade openness, infrastructural development, etc.

iii. The observation of positive and significant effect of access to electricity on labour productivity further underscores the need for massive investment in power/electricity generation and, development of efficient channels of distribution. This will no doubt boost labour productivity in the country. 


\subsection{Conclusion}

The study examined the effects of import competition and other macroeconomic factors namely capital intensity, FDI and access to electricity on labour productivity in Nigeria during the period from 1991 to 2018 . The FMOLS estimator was employed for the analysis. The study found that import competition adversely (negatively and significantly) affected labour productivity in the country. It also found positive but not significant effect of capital intensity on labour productivity. Further evidence from the study were that FDI (which is a key mechanism for technology transfer by multinational corporations) and increased access to electricity positively and significantly affected labour productivity in the country. Based on the findings, recommendations were made for formulation of policies targeted at enhancing productivity of labour in the country in her quest for sustainable growth and development.

\section{References}

Akinleye, S. T., 2007. A Critical Assessment of Environmental Impact on Workers' Productivity in Nigeria. Research Journal of Business Management, 1 (1), pp. 50-61.

Alam, M. S., Miah, M. D., Hammoudeh, S. and Tiwari, A. K., 2018. The Nexus between Access to Electricity and Labour Productivity in Developing Countries. Energy Policy, 122, pp. 715-726.

Bloch, H. and McDonald, J. T, 2001. Import Competition and Labor Productivity. Journal of Industry, Competition and Trade, 1 (3), pp. 301-309.

Boghean, C. and State, M., 2015. The Relation between Foreign Direct Investments (FDI) and Labour Productivity in the European Union Countries. Procedia Economics and Finance, 32, pp. 278-285.

Dhyne, E., Petrin, A., Smeets, V. and Warzynski, F., 2016. Multi-Product Firms, Import Competition, and the Evolution of Firm-product Technical Efficiencies. [Online] Available at:https://editorialexpress.com/cgibin/conference/download.cgi?db name=SED2017\&pape $r$ id=242, [accessed 22.03.2019].

Ding, S., Sun, P and Jiang, W., 2015. The Effect of Import Competition on Firm Productivity and Innovation: Does the Distance to Technology Frontier Matter? Oxford Bulletin of Economics and Statistics, 78 (2), pp. 197-227.

Doan, T., Nguyen, S., Vu, H., Tran, T and Lim, S., 2014. Does Rising Import Competition Harm Local Firm Productivity in Less Advanced Economies? Evidence from the Vietnam's Manufacturing Sector. The Journal of International Trade and Economic Development, 25 (1), pp. 23-46.

Fagbenle, O. I, Ogunde, A. O. and Owolabi, J. D., 2011. Factors Affecting the Performance of Labour in Nigerian Construction Sites. Mediterranean Journal of Social Sciences, 2 (2), pp. 251-257.

International Labour Organisation, Labour Productivity. [pdf]. Available at: https://www.ilo.org/ilostat-files/Documents/description PRODY EN.pdf, [accessed 23.04.2019].

Jimoh, R., Oyewobi, L., Suleiman, S. and Isa, R., 2017. Influence of Supervision on Labour Productivity on Construction Sites in Abuja-Nigeria. Independent Journal of Management and Production, 8 (1), pp. 64-81.

Krugman, P., 1995. Cycles of Conventional Wisdom on Economic Development. International Affairs, 71 (4), pp. 717-732.

Liu, X., Parker, D., Vaidya, K and Wei, Y., 2001. The Impact of Foreign Direct Investment on Labour Productivity in the Chinese Electronics Industry. International Business Review, 10 (4), pp. 421-439.

MacDonald, J. M., 1994. Does Import Competition Force Efficient Production? The Review of Economics and Statistics, 76 (4), pp. 721-727. 
Muhammad, N. Z., Sani, A, Muhammad, A., Balubaid, S, Ituma, E. E., Suleiman, J. H., 2015. Evaluation of Factors Affecting Labour Productivity in Construction Industry: A Case Study. Universiti Teknologi Malaysia (UTM) Jurnal Teknologi (Sciences and Engineering), 77(12), pp. 87-91.

Murphy, G. and Siedschlag, I., 2012. The Effect of Real Exchange Rate Changes on Labour Productivity Growth. Economic and Social Research Institute (ESRI) Working Paper, No. WP439.

Nekrep, A., Strašek, S. and Boršič, D., 2018. Productivity and Economic Growth in the European Union: Impact of Investment in Research and Development. Naše gospodarstvo/Our Economy, 64 (1), pp. 18-27. DOI: 10.2478/ngoe-2018-0003.

Olper, A., Pacca, L. and Curzi, D., 2013. Trade, Import Competition and Productivity Growth in the Food Industry. COMPETE Working Paper No. 3. December.

Ospinar, S. and Schiffbauer, M., 2010. Competition and Firm Productivity: Evidence from Firm-Level Data. IMF Working Paper No. WP/10/67, March.

Phillips, P. C. B. and Hansen, B. E., 1990. Statistical Inference in Instrumental Variables Regression with I(1) Process. Review of Economic Studies, 57, pp. 99-125

Ramirez, M. D., 2006. Does Foreign Direct Investment Enhance Labor Productivity Growth in Chile? A Cointegration Analysis. Eastern Economic Journal, 32 (2), pp. 205-220.

Reenen, J. V., 2010. Does Competition Raise Productivity through Improving Management Quality? Centre for Economic Performance Working Paper, No. 1036, December.

Turcan, K. and Ates, A., 2010. Structure and Determinants of Intra-Industry Trade in the U. S. Auto-Industry. Journal of International and Global Economic Studies, 2 (2), pp. 15-46.

Umoru, D and Yaqub, J. O., 2013. Labour Productivity and Health Capital in Nigeria: The Empirical Evidence. International Journal of Humanities and Social Science, 3 (4), pp. 199-221.

World Bank, 2019. World Bank List of Countries (Classification by Income Dataset). Washington DC: The World Bank.

World Trade Organisation, 1984. General Agreement on Tariffs and Trade. Geneva: World Trade Organisation.

Yahmed, B. and Dougherty, S., 2016. Domestic Regulation, Import Penetration and Firm-Level Productivity Growth. The Journal of International Trade and Economic Development, 26(4), pp. 385-409.

\section{Bio-note}

Oziengbe Scott Aigheyisi is an economist. His main research interests and areas of specialisation are International Trade and Finance, Monetary Economics, Development Economics, Financial Analysis and Applied Econometrics. 